\title{
Recurrence of Differentiated Thyroid Carcinoma During Full TSH Suppression: Is the Tumor Now Thyroid Hormone Dependent?
}

\author{
Paul J. Davis • Aleck Hercbergs • Mary K. Luidens • \\ Hung-Yun Lin
}

Received: 26 August 2014 / Accepted: 29 September 2014 /Published online: 8 October 2014

(C) The Author(s) 2014. This article is published with open access at Springerlink.com

\begin{abstract}
Well-standardized primary treatment and longterm management of differentiated thyroid carcinoma (DTC) include lowering or suppression of host thyrotropin (TSH) with exogenous L-thyroxine $\left(\mathrm{T}_{4}\right)$. This treatment recognizes the trophic action of TSH on DTC cells. Suppression of endogenous TSH with $\mathrm{T}_{4}$ is continued in recurrent disease. However, $\mathrm{T}_{4}$ can induce proliferation of follicular and papillary thyroid carcinoma cell lines and of other human carcinoma cells. The proliferative mechanism is initiated at a cell surface receptor for $T_{4}$ on integrin $\alpha v \beta 3$, a receptor by which the hormone also inhibits p53-dependent apoptosis in tumor cells. In recurrent DTC with satisfactory suppression of endogenous TSH, we discuss here the possibility that the tumor is no longer TSH dependent and that $\mathrm{T}_{4}$ has become a critical growth factor for the cancer.
\end{abstract}

P. J. Davis • M. K. Luidens

Department of Medicine, Albany Medical College, Albany, NY, USA

\section{P. J. Davis ( $\square)$}

Pharmaceutical Research Institute, Albany College of Pharmacy and Health Sciences, One Discovery Drive, Rensselaer, NY 12144, USA e-mail: pdavis.ordwayst@gmail.com

A. Hercbergs

Department of Radiation Oncology, Cleveland Clinic, Cleveland, $\mathrm{OH}$, USA

\section{H.-Y. Lin}

PhD Program for Cancer Biology and Drug Discovery, College of Medical Science and Technology, Taipei Medical University, Taipei, Taiwan

\section{Management of Differentiated Thyroid Carcinoma}

Differentiated thyroid carcinoma (DTC) accounts for about $90 \%$ of thyroid cancers [40]. Initial and long-term management guidelines provided by the American Thyroid Association have worked to standardize the surgical, radioablative, and medical treatment of differentiated thyroid carcinoma (DTC) [16] and have drawn a number of substantial comments $[63,70,73]$. A key feature of DTC treatment is the lowering in low risk or the suppression in higher risk DTC patients of circulating endogenous pituitary thyrotropin (TSH). Reduction of patient TSH release is achieved with exogenous thyroid hormone (L-thyroxine, $\mathrm{T}_{4}$ ). TSH is a growth factor for papillary and follicular thyroid cancer, and successful TSH suppression therapy assumes a functional TSH receptor (TSHR) in thyroid cells whose activity is minimized by the dearth of circulating TSH. The risks and benefits of TSH suppression therapy have been reviewed in detail by Biondi and Cooper [4].

Recurrence of disease occurs in $15 \%$ or more of DTC patients [52], with a higher incidence of recurrence in patients over the age of 65 years [34]. Recurrence may be a product of patient noncompliance with the TSH suppression regimen, but, in the compliant patient, the molecular basis of recurrent tumor is not clear. The tumor cell TSH receptor (TSHR) may be a hyperfunctional mutant in DTC (2726) and thus may respond over time in residual cancer cells to low-butdetectable circulating levels of TSH. However, the frequency of TSHR mutations in DTC is variable [9]. The state of $\mathrm{p} 53$ in the remaining tumor cells may also determine lesion aggressiveness [57]. That a silenced TSHR is often present in the case of undifferentiated thyroid cancers $[28,54]$ is certainly consistent with the existence of endogenous growth or regulatory factors that are alternatives to TSH and may support 
thyroid tumor cell proliferation. There are a number of examples of such factors, including the epidermal growth factor (EGF) axis [39, 82] and platelet-derived growth factor (PDGF) [29, 83]. While it is important to growth of various cancers, the EGF receptor in papillary DTC in terms of abundance and affinity appears to be the same in tumoral and adjacent normal thyroid tissue [53]. On the other hand, PDGF may promote lymphatic metastases in DTC [83], and vascular endothelial growth factor (VEGF) supports development of lymph node metastases from DTC, at least in certain ethnic populations [10]. Insulin-like growth factor 1 (IGF-1) is a trophic factor for DTC [69]. Thyroid transcription factor 1 (TTF-1) may be localized to the nucleus in differentiated thyroid carcinoma with increased frequency in the settings of recurrent or persistent disease [27]. Hormonal regulation of TTF-1 has not been well studied [5].

Certain gene mutations occur in DTC but have had variable success as predictors of recurrence. BRAF mutations, particularly V600E, have drawn particular attention in DTCs $[1,18$, 26, 37, 66].

Given the above information, the possibility should be considered that additional endogenous growth factors exist for DTC in the absence of TSH that will support recurrence. One such factor is thyroid hormone (see next section) which has been shown to have proliferative effects on follicular and papillary thyroid carcinoma cells [48].

\section{Proliferative and Anti-apoptotic Actions of Thyroid Hormone at Integrin $\alpha v \beta 3$ on DTC and Other Tumor Cells}

Integrin $\alpha \mathrm{v} \beta 3$ is a structural protein of the plasma membrane that binds specific extracellular matrix proteins and is critical to cell-cell and cell-matrix interactions $[64,76]$. It is amply expressed by and activated in cancer cells and rapidly dividing blood vessel cells [21]. The protein has been recently appreciated to contain small molecular receptor sites for androgen [45], resveratrol [43], and thyroid hormone [2, 21, 41]. Acting at its receptor on $\alpha \mathrm{v} \beta 3$, thyroid hormone (L-thyroxine, $\mathrm{T}_{4}$; 3,5,3'-triiodo-L-thyronine, $\mathrm{T}_{3}$ ) has been shown to be proangiogenic $[12,20,51]$ and to induce proliferation in a variety of human cancer cells. The latter includes glioblastoma [46], lung [55], pancreas [81], and kidney [79] cells. The thyroid hormone receptor on the integrin has no structural homologies with the classical nuclear thyroid hormone receptor (TR) [14, 41]. The $\alpha v \beta 3$-based actions of the hormone are nongenomic, in that they are independent of the $\mathrm{T}_{3}$-TR interactions that are the basis of the genomic mechanism of hormone action. From the integrin, however, $\mathrm{T}_{4}$ can modulate genomic actions of $\mathrm{T}_{3}$ [22] by affecting the trafficking of TR from cytoplasm to nucleus [8], the state of phosphorylation of TR [23], and the formation of TR-coactivator protein complexes [44]. The presence of $\alpha \mathrm{v} \beta 3$ has been confirmed in the many solid tumor cell lines with which we have worked (HY Lin; unpublished observations), regardless of putatively aggressive phenotype. Studies by others in nonthyroid solid tumor cell lines have indicated that $\alpha v \beta 3$ confers recurrence behavior when other factors, such as chemokine CCL2 [49] or matrix metalloproteinase-9 (MMP-9) [33], are also present.

As noted above, we have shown that follicular thyroid cancer cells and papillary thyroid carcinoma cells [48] proliferate in vitro in response to $T_{4}$ at physiologic free concentrations. The proliferative response requires MAPK (ERK1/2) activation and is blocked by RGD peptide, indicating the effect is initiated at the hormone receptor site on $\alpha \mathrm{v} \beta 3$. These observations raise the possibility that endogenous thyroid hormone can be a growth factor for undiagnosed thyroid cancer. That in patients with an established diagnosis of DTC there may be recurrent local and metastatic thyroid cancer despite successful suppression of endogenous TSH release with pharmacologic thyroid hormone may have trophic effects on the recurrent tumor. The proliferative effect of $\mathrm{T}_{4}\left(10^{-10} \mathrm{M}\right.$ free hormone) on thyroid cancer cells has been observed in nonmutant cell lines, including TTF-1-expressing cells, in Ret/PC1-positive cells [48], and in heterozygous BRAF(V600E)/wt cells (HY Lin: unpublished observations).

A second approach which has been used to examine the proliferative actions of thyroid hormone on DTC cells in vitro involves tetraiodothyroacetic acid (tetrac), the naturally occurring deaminated analog of $\mathrm{T}_{4}$. Tetrac inhibits the trophic effects of $T_{4}$ and $T_{3}$ on a variety of tumor cells $[46,47,55]$, including papillary and follicular cancer cells [48]. This action depends upon inhibition by tetrac of the binding of thyroid hormone to integrin $\alpha v \beta 3$ [20]. Tetrac formulations - including nanoparticulate tetrac that is excluded from the cell interior-have been shown to arrest the growth of human follicular thyroid carcinoma xenografts [78], xenografts of medullary thyroid carcinoma [80], and other human solid tumor xenografts $[58,79,81]$. Such observations are consistent with actions of thyroid hormone as a trophic factor for cancers, including DTC. But, it should be noted that tetrac has anti-cancer and anti-angiogenic effects that are additive to its activity as an inhibitor of iodothyronine binding to the integrin [21].

Thyroid hormone has a number of other actions that may support solid tumor growth. The hormone is pro-angiogenic $[19,51]$ by several mechanisms, including enhancement of the angiogenic activities of VEGF, FGF2 (bFGF), and PDGF [51]. Interestingly, the hormone may inhibit proliferative action of IGF-1 in myoblasts [36] but amplifies IGF-1 signaling in chondrocytes [74] and other cells [61]. This suggests that thyroid hormone effects on this growth factor are complex and may be tissue specific. The hormone stimulates miR-21 production that enhances metastasis [35], as does hormonal action to repress miR-17 [50]. The hormone causes transcription 
of a panel of metalloproteinase genes (MMP-2, MMP-3 [60], and $M M P-9[15,60,65])$ that support tumor dispersal/metastasis. A number of these actions are initiated at integrin $\alpha \mathrm{v} \beta 3$. Differential expression of genes in cancer cells that code for regulatory proteins important to the cell cycle is also stimulated by thyroid hormone [71]. Thyroid hormone has antiapoptotic actions in a variety of cells $[11,13,25,42,47,48$, $62,67,72,84]$. We have shown that the hormone can block pharmacologic induction of p53-dependent apoptosis [48] by interfering with Ser-15 phosphorylation of $\mathrm{p} 53$. We would point out that the hormone has also been reported to cause apoptosis, but the models typically involve hyperthyroidism in intact animals or very high doses of the hormone in vitro, e.g., $250-500 \mu \mathrm{M}[75,77]$. Finally, the pro-angiogenic activity of thyroid hormone [51] may be interpreted as a support mechanism for cancers.

The affinity of the thyroid hormone receptor on plasma membrane integrin $\alpha v \beta 3$ is higher for $T_{4}$ than $T_{3}$ [2]. Functionally, this means that supraphysiologic amounts of $\mathrm{T}_{3}$ are required to induce proliferation in vitro, as shown, for example, in human glioblastoma cells [46]. In contrast, concentrations of free $\mathrm{T}_{4}$ of $10^{-10} \mathrm{M}$ or less are proliferative. This has raised the possibility of lowering tumor patient circulating $\mathrm{T}_{4}$ levels via suppression of patient TSH with antithyroid drug therapy [32] or exogenous $\mathrm{T}_{3}[30,31]$. This strategy is discussed in the next section.

\section{Is Recurrent DTC in Part an Expression of Actions of Thyroid Hormone?}

This question is not a denial of the role of TSH in support of differentiated thyroid cancer or of the utility of the lowering of TSH or its suppression in this clinical setting. We would agree that in the large majority of DTC patients, the relative importance of TSH and the proliferative and/or anti-apoptotic activity of thyroid hormone used to suppress endogenous TSH strongly favors the contribution of endogenous TSH and is a requirement for its suppression.

On the other hand, the mechanisms for recurrence or relapse of well-differentiated papillary or follicular thyroid cancer in the fully TSH-suppressed patient have not been satisfactorily defined. That thyroid hormone, notably as $\mathrm{T}_{4}$, stimulates tumor cell proliferation and is anti-apoptotic has been repeatedly demonstrated $[42,47,48]$ in a variety of cell lines in vitro, including follicular and papillary thyroid cancer cells, as noted above. The $\alpha v \beta 3$ integrin that mediates such hormonal activity is amply expressed by cancer cells and by endothelial cells involved in tumor-related angiogenesis. This mechanism is independent of nuclear TR.

There are several strategies that may be discussed to test the concept that $\mathrm{T}_{4}$ used to suppress endogenous TSH may contribute adversely to tumor behavior in patients with recurrent
DTC. First, TSH-suppressive administration of $\mathrm{T}_{3}$ may be substituted for L-thyroxine. $\mathrm{T}_{3}$ may be administered sufficiently frequently to assure suppression of endogenous TSH and achieve frank reduction in circulating $\mathrm{T}_{4}$ levels. The clinical endpoint is number and size of recurrent tumors. This approach anecdotally has resulted in decreased size of certain cancers [30,31], but has not been tested against DTC.

Second, when recurrent DTC occurs in the setting of full TSH suppression with $T_{4}$, the treatment with $T_{4}$ may be interrupted for several months. The TSH may be allowed to rise into the normal range or higher, and symptomatic hypothyroidism would be managed with sufficient L-thyroxine to abolish symptoms. The intent of reinstitution of $\mathrm{T}_{4}$ treatment is not to return serum TSH to the normal range, but only to relieve symptoms. The clinical endpoint again is number and size of recurrent tumors. Without satisfactory documentation that, in fact, $\mathrm{T}_{4}$ has replaced TSH as a growth factor for the tumor, this approach cannot be used.

Third, thyroid hormone responsiveness of biopsied recurrent, invasive DTC might be tested in one or model systems. One such approach involves xenografting of tumor biopsy cells into the chick chorioallantoic membrane (CAM) system, with biomarker response testing of the cells to TSH and, separately, to $\mathrm{T}_{4}$. The results may then direct subsequent management. This is a personalized medicine approach that we have elsewhere suggested may be used in the future to define pharmacodynamics of multiple chemotherapeutic agents against recurrent cancers of various types [24]. Tumor cell radiosensitivity can also be evaluated in the CAM.

A final point for discussion is that deaminated thyroid hormone analogs are agents that suppress pituitary TSH secretion. Tetrac [7] and triac [6, 7, 38] have been shown to be effective inhibitors of TSH secretion and have been considered for use in the setting of thyroid cancer. As discussed above, tetrac also blocks the proliferative actions of $T_{4}$ on tumor cells that are initiated at $\alpha \mathrm{v} \beta 3[21,41]$ and triac also has been shown to inhibit nongenomic actions of $\mathrm{T}_{4}$ [19]. The use of either of these agents may suppress host TSH and, independently of this action, inhibit DTC tumor cell proliferation. The approach has an important disadvantage. Unmodified tetrac and triac are taken up by nonmalignant cells and are thyromimetic in such cells [56], albeit low grade. Such thyromimetic effects in noncancer cells may have interrupted the proposed commercial development of unmodified tetrac as a TSH-suppressing drug. In contrast, nanoparticulate tetraca compound in which the tetrac is covalently bound to a biodegradable nanoparticle $[3,21]$ - is not internalized by any cells and expresses its anti-tumor and anti-angiogenic activity exclusively at $\alpha v \beta 3$ in the plasma membrane. Limited to the cell exterior, however, nanoparticulate tetrac is not a suppressor of pituitary TSH secretion.

A section of the guidelines of the American Thyroid Association for management of DTC includes an essay on 
directions for future research [16]. Emphases are placed on disruption of oncogenic signaling pathways, particularly MAPK, on modulation of proliferation and apoptosis and on development or use of inhibitors of angiogenesis. These themes appear to us to be very relevant to the possibility we raise here that TSH-suppressive doses of $\mathrm{T}_{4}$ in the patient population with recurrent, aggressive DTC may then contribute to the clinical growth of the tumor. The proliferative actions of $T_{4}$ initiated at $\alpha \mathrm{v} \beta 3$ are MAPK dependent [46]; $\mathrm{T}_{4}$ is anti-apoptotic $[42,47,48]$ and $\mathrm{T}_{4}$ is pro-angiogenic [20, 51]. Thus, consideration of the elimination of these actions of $\mathrm{T}_{4}$ in cancer cells that express $\alpha \mathrm{v} \beta 3$ has some attractiveness. Studies to determine whether $T_{4}$ is a proliferative factor in xenografts have not yet been carried out, but induced or spontaneous hypothyroidism in patients with glioblastoma [32], renal cell carcinoma [68], nonthyroidal head and neck cancers [59], and breast carcinoma [17] has favorably affected tumor behavior.

Conflicts of interest The authors have no conflicts of interest to declare.

Open Access This article is distributed under the terms of the Creative Commons Attribution License which permits any use, distribution, and reproduction in any medium, provided the original author(s) and the source are credited.

\section{References}

1. Albarel F, Conte-Devoix B, Oliver C (2012) From nodule to differentiated thyroid carcinoma: contributions of molecular analysis in 2012. Ann Endocrinol (Paris) 73:155-164

2. Bergh JJ, Lin HY, Lansing L, Mohamed SN, Davis FB, Mousa S, Davis PJ (2005) Integrin alphavbeta3 contains a cell surface receptor site for thyroid hormone that is linked to activation of mitogenactivated protein kinase and induction of angiogenesis. Endocrinology 146:2864-2871

3. Bharali DJ, Yalcin M, Davis PJ, Mousa SA (2013) Tetraiodothyroacetic acid-conjugated PLGA nanoparticles: a nanomedicine approach to treat drug-resistant breast cancer. Nanomedicine (London) 8:1943-1954

4. Biondi B, Cooper DS (2010) Benefits of thyrotropin suppression versus the risks of adverse effects in differentiated thyroid cancer. Thyroid 20:135-146

5. Boggaram V (2009) Thyroid transcription factor-1 (TTF-1/Nkx2.1/ TITF1) gene regulation in the lung. Clin Sci 116:27-35

6. Bracco D, Morin O, Schutz Y, Liang H, Jequier E, Burger AG (1993) Comparison of the metabolic and endocrine effects of 3, 5, 3'triiodothyroacetic acid and thyroxine. J Clin Endocrinol Metab 77: 221-228

7. Burger AG, Engler D, Sakoloff C, Staeheli V (1979) The effects of tetraiodothyroacetic and triiodothyroacetic acids on thyroid function in euthyroid and hyperthyroid subjects. Acta Endocrinol (Copenh) 92:455-467

8. Cao HJ, Lin HY, Luidens MK, Davis FB, Davis PJ (2009) Cytoplasm-to-nucleus shuttling of thyroid hormone receptor-beta1
(TRbeta1) is directed from a plasma membrane integrin receptor by thyroid hormone. Endocr Res 34:31-42

9. Cetani F, Tonacchera M, Pinchera A, Barsacchi R, Basolo F, Miccoli P, Pacini F (1999) Genetic analysis of the TSH receptor gene in differentiated human thyroid carcinomas. J Endocrinol Invest 22: 273-278

10. Chang DF, Xu ZQ, Sun B (2014) Relationship between VEGF protein expression and lymph node metastasis in papillary thyroid carcinoma among Asians: a meta-analysis. Tumour Biol 35: $5511-5518$

11. Chen YF, Kobayashi S, Chen J, Redetzke RA, Said S, Liang Q, Gerdes AM (2008) Short term triiodo-L-thyronine treatment inhibits cardiac myocyte apoptosis in border area after myocardial infarctions in rats. J Mol Cell Cardiol 44:180-187

12. Chen YF, Ortmeier SB, Savinova OV, Nareddy VB, Beyer AJ, Wang D, Gerdes AM (2012) Thyroid hormone induces sprouting angiogenesis in adult heart of hypothyroid mice through the PDGF-Akt pathway. J Cell Mol Med 16:2726-2735

13. Chi HC, Chen SL, Liao CJ, Lio CH, Tsai MM, Lin YH, Huang YH, Yeh CT, Wu SM, Tseng YH, Chen CY, Tsai CY, Chung IH, Chen WJ, Lin KH (2012) Thyroid hormone receptors promote metastasis of human hepatoma cells via regulation of TRAIL. Cell Death Differ 19: $1802-1814$

14. Cody V, Davis PJ, Davis FB (2007) Molecular modeling of the thyroid hormone interactions with alpha $\mathrm{v}$ beta3 integrin. Steroids $72: 165-170$

15. Cohen K, Flint N, Shalev S, Erez D, Baharal T, Davis PJ, Hercbergs A, Ellis M, Ashur-Fabian O (2014) Thyroid hormone regulates adhesion, migration and matrix metalloproteinase 9 activity via $\alpha \mathrm{v} \beta 3$ integrin in myeloma cells. Oncotarget 5:6312-6322

16. Cooper DS, Doherty GM, Haugen BR, Kloos RT, Lee SL, Mandel SJ, Mazzaferri EL, McIver B, Pacini F, Schlumberger M, Sherman SI, Steward DL, Tuttle RM (2009) Revised American Thyroid Association management guidelines for patients with thyroid nodules and differentiated thyroid cancer. Thyroid 19:1167-1214

17. Cristofanilli M, Yamamura Y, Kau SW, Bevers T, Strom S, Patangan M, Hsu L, Krishnamurthy S, Theriault RL, Hortobagyi GN (2005) Thyroid hormone and breast carcinoma. Primary hypothyroidism is associated with a reduced incidence of primary breast cancer. Cancer 103:1122-1128

18. Danilovic DL, Lima EU, Domingues RB, Brandao LG, Hoff AO, Marui S (2014) Pre-operative role of BRAF in the guidance of the surgical approach and prognosis of differentiated thyroid carcinoma. Eur J Endocrinol 170:619-625

19. D'Arezzo S, Incerpi S, Davis FB, Acconcia F, Marino M, Farias RN, Davis PJ (2004) Rapid nongenomic effects of 3, 5, 3'-triiodo-Lthyronine on the intracellular $\mathrm{pH}$ of L- 6 myoblasts are mediated by intracellular calcium mobilization and kinase pathways. Endocrinology 145:5694-5703

20. Davis FB, Mousa SA, O’Connor L, Mohamed S, Lin HY, Cao HJ, Davis PJ (2004) Proangiogenic action of thyroid hormone is fibroblast growth factor-dependent and is initiated at the cell surface. Circ Res 94:1500-1506

21. Davis PJ, Davis FB, Mousa SA, Luidens MK, Lin HY (2011) Membrane receptor for thyroid hormone: physiologic and pharmacologic implications. Annu Rev Pharmacol Toxicol 51:99115

22. Davis PJ, Lin HY, Tang HY, Davis FB, Mousa SA (2013) Adjunctive input to the nuclear thyroid hormone receptor from the cell surface receptor for thyroid hormone. Thyroid 23:1503-1509

23. Davis PJ, Shih A, Lin HY, Martino LJ, Davis FB (2000) Thyroxine promotes association of mitogen-activated protein kinase and nuclear thyroid hormone receptor (TR) and causes serine phosphorylation of TR. J Biol Chem 275:38032-38039

24. Davis PJ, Yalcin M, Lin HY, Tang HY, Hercbergs A, Leith JT, Davis FB, Luidens MK, Mousa SA (2014) Incomplete success of 
angioinhibitor therapy in cancer: estimation of contribution of proangiogenic activity of patient thyroid hormone. J Cancer Sci Ther 5: $441-445$

25. Deb I, Das S (2001) Thyroid hormones protect astrocytes from morphine-induced apoptosis by regulating nitric oxide and pERK $1 / 2$ pathways. Neurochem Int 58:861-871

26. Elisei R, Viola D, Torregrossa L, Giannini R, Romei C, Ugolini C, Molinaro E, Agate L, Biagini A, Lupi C, Valerio L, Materazzi G, Miccoli P, Piaggi P, Pinchera A, Vitt P, Basolo F (2012) The BRAF (V600E) mutation is an independent, poor prognostic factor for the outcome of patients with low-risk intrathyroid papillary thyroid carcinoma: single-institution results from a large cohort study. J Clin Endocrinol Metab 97:4390-4398

27. Fenton CF, Patel A, Burch HB, Tuttle RM, Francis GL (2001) Nuclear localization of thyroid transcription factor-1 correlates with serum thyrotropin activity and may be increased in differentiated thyroid carcinomas with aggressive clinic course. Ann Clin Lab Sci $31: 245-252$

28. Garcia-Jimenez C, Santisteban P (2007) TSH signaling and cancer. Arq Bras Endocrinol Metabol 51:654-671

29. Heldin NE, Cvejic D, Smeds S, Westermark B (1991) Coexpression of functionally active receptors for thyrotropin and platelet-derived growth factor in human thyroid carcinoma cells. Endocrinology 129: 2187-2193

30. Hercbergs A (2013) Effect of exogenous triiodothyronine (T3) on free thyroxine depletion and tumor response: a compassionate care study. J Clin Oncol 31:e22077

31. Hercbergs AA, Garfield D, Ashur-Fabian O, Davis PJ (2012) Thyroid dysfunction from antineoplastic agents. J Natl Cancer Inst 104:422-423

32. Hercbergs AA, Goyal LK, Suh JH, Lee S, Reddy CA, Cohen BH, Stevens GH, Reddy SK, Peereboom DM, Elson PJ, Gupta MK, Barnett GH (2003) Propylthiouracil-induced chemical hypothyroidism with high-dose tamoxifen prolongs survival in recurrent high grade glioma: a phase I/II study. Anticancer Res 23:617-626

33. Hoffman UB, Westphal JR, Waas ET, Becker JC, Ruiter DJ, van Muijen GN (2000) Coexpression of integrin alpha(v)beta3 and matrix metalloproteinase-2 (MMP-2) coincides with MMP-2 activation: correlation with melanoma progression. J Invest Dermatol 115:625-632

34. Hollenbeak CS, Boltz MM, Schaefer EW, Saunders BD, Goldenberg D (2013) Recurrence of differentiated thyroid cancer in the elderly. Eur J Endocrinol 168:549-556

35. Huang YH, Lin YH, Chi HC, Liao CH, Liao CJ, Wu SM, Chen CY, Tseng YH, Tsai CY, Lin SY, Hung YT, Wang CJ, Lin CD, Lin KH (2013) Thyroid hormone regulation of miR-21 enhances migration and invasion of hepatoma. Cancer Res 73:2505-2517

36. Incerpi S, Hsieh MT, Lin HY, Cheng GY, De Vito P, Fiore AM, Ahmed RG, Salvia R, Candelotti E, Leone S, Luly P, Pedersen JZ, Davis FB, Davis PJ (2014) Thyroid hormone inhibition in L6 myoblasts of IGF-1-mediated glucose uptake and proliferation: new roles for integrin $\alpha \mathrm{v} \beta 3$. Am J Physiol Cell Physiol 307:C150-C161

37. Jing FJ, Liang J, Liang ZY, Meng C, Long W, Li XY, Lin YS (2013) $\mathrm{BRAF}(\mathrm{V} 600 \mathrm{E})$ mutation is not a positive predictor for distant metastasis in sporadic papillary thyroid carcinoma. Chin Med J (Engl) 126: 3013-3018

38. Juge-Aubry CE, Morin O, Pernin AT, Liang H, Philippe J, Burger AG (1995) Long-lasting effects of triac and thyroxine on the control of thyrotropin and hepatic deiodinase type 1. Eur J Endocrinol 132:751758

39. Landriscina M, Piscazzi A, Fabiano A, Maddalena F, Constantino A, Farese A, Bufo P, Cignarelli M (2009) Targeting epidermal growth factor receptor 1 signaling in human thyroid-stimulating hormoneindependent thyroid carcinoma FRO cells results in a more chemosensitive and less angiogenic phenotype. Thyroid 19:629-637

40. Liao S, Shindo M (2012) Management of well-differentiated thyroid cancer. Otolaryngol Clin N Am 45:1163-1179
41. Lin HY, Cody V, Davis FB, Hercbergs AA, Luidens MK, Mousa SA, Davis PJ (2011) Identification and functions of the plasma membrane receptor for thyroid hormone analogues. Discov Med 11:337-347

42. Lin HY, Davis PJ, Tang HY, Mousa SA, Luidens MK, Hercbergs AH, Davis FB (2009) The pro-apoptotic action of stilbene-induced COX2 in cancer cells: convergence with the anti-apoptotic effect of thyroid hormone. Cell Cycle 8:1877-1882

43. Lin HY, Lansing L, Merillon JM, Davis FB, Tang HY, Shih A, Vitrac X, Krisa S, Keating T, Cao HJ, Bergh J, Quackenbush S, Davis PJ (2006) Integrin alphavbeta3 contains a receptor site for resveratrol. FASEB J 20:1742-1744

44. Lin HY, Su YF, Hsieh MT, Lin S, Meng R, London D, Lin C, Tang HY, Hwang J, Davis FB, Mousa SA, Davis PJ (2013) Nuclear monomeric integrin $\alpha \mathrm{V}$ is a coactivator regulated by thyroid hormone. FASEB J 27:3209-3216

45. Lin HY, Sun M, Lin C, Tang HY, London D, Shih A, Davis FB, Davis PJ (2009) Androgen-induced human breast cancer cell proliferation is mediated by discrete mechanisms in estrogen receptor-alpha-positive and -negative breast cancer cells. J Steroid Biochem Molec Biol 113: 182-188

46. Lin HY, Sun M, Tang HY, Lin C, Luidens MK, Mousa SA, Incerpi S, Drusano GL, Davis FB, Davis PJ (2009) L-Thyroxine vs. 3, 5, 3'triiodo-L-thyronine and cell proliferation: activation of mitogenactivated protein kinase and phosphatidylinositol 3-kinase. Am J Physiol Cell Physiol 296:C980-C991

47. Lin HY, Tang HY, Keating T, Wu YH, Shih A, Hammond D, Sun M, Hercbergs A, Davis FB, Davis PJ (2008) Resveratrol is pro-apoptotic and thyroid hormone is anti-apoptotic in glioma cells: both actions are integrin and ERK mediated. Carcinogenesis 29:62-69

48. Lin HY, Tang HY, Shih A, Keating T, Cao G, Davis PJ, Davis FB (2007) Thyroid hormone is a MAPK-dependent growth factor for thyroid cancer cells and is anti-apoptotic. Steroids 72:180-187

49. Lin TH, Liu HH, Tsai TH, Chen CC, Hsieh TF, Lee SS, Lee YJ, Chen WC, Tang CH (2013) CCL2 increases $\alpha \mathrm{v} \beta 3$ integrin expression and subsequently promotes prostate cancer migration. Biochim Biophys Acta 1830:4917-4927

50. Lin YH, Liao CJ, Huang YH, Wu MH, Chi HC, Wu SM, Chen CY, Tseng YH, Tsai CY, Chung IH, Wu TI, Tsai MM, Lin CD, Lin JH (2013) Thyroid hormone receptor represses miR-17 expression to enhance tumor metastasis in human hepatoma cells. Oncogene 32: $4509-4518$

51. Luidens MK, Mousa SA, Davis FB, Lin HY, Davis PJ (2010) Thyroid hormone and angiogenesis. Vasc Pharmacol 52:142-145

52. Magarey MJ, Freeman JL (2013) Recurrent well-differentiated thyroid carcinoma. Oral Oncol 49:689-694

53. Makinen T, Pekonen F, Freanssila K, Lamberg BA (1988) Receptors for epidermal growth factor and thyrotropin in thyroid carcinoma. Acta Endocrinol (Copenh) 117:45-50

54. Matsumoto H, Sakamoto A, Fujiwara M, Yano Y, Shisido-Hara Y, Fujioka Y, Kamma H (2008) Decreased expression of the thyroidstimulating hormone receptor in poorly-differentiated carcinoma of the thyroid. Oncol Rep 19:1405-1411

55. Meng R, Tang HY, Westfall J, London D, Cao JH, Mousa SA, Luidens M, Hercbergs A, Davis FB, Davis PJ, Lin HY (2011) Crosstalk between integrin $\alpha \mathrm{v} \beta 3$ and estrogen receptor- $\alpha$ is involved in thyroid hormone-induced proliferation in human lung carcinoma cells. PLoS One 6(11):e27547

56. Moreno M, de Lange P, Lombardi A, Silvestri E, Lanni A, Goglia F (2008) Metabolic effects of thyroid hormone derivatives. Thyroid 18: 239-253

57. Moretti F, Farsetti A, Soddu S, Misiti S, Crescenzi M, Filetti S, Andreoli M, Sacchi A, Pontecorvi A (1997) p53 re-expression inhibits proliferation and restores differentiaion of human thyroid anaplastic carcinoma cells. Oncogene 14:729-740

58. Mousa SA, Yalcin M, Bharali DJ, Meng R, Tang HY, Lin HY, Davis FB, Davis PJ (2012) Tetraiodothyroacetic acid and its 
nanoformulation inhibition thyroid hormone stimulation of nonsmall cell lung cancer cells in vitro and their growth in xenografts. Lung Cancer 76:39-45

59. Nelson M, Hercbergs A, Rybicki L, Strome M (2006) Association between development of hypothyroidism and improved survival in patients with head and neck cancer. Arch Otolaryngol Head Neck Surg 132:1041-1046

60. Oki M, Matsuo H, Nakago S, Murakoshi H, Laoag-Fernandez JB, Maruo T (2004) Effects of 3, 5, 3'-triiodothyronine on the invasive potential and the expression of integrins and matrix metalloproteinases in cultured early placental extravillous trophoblasts. J Clin Endocrinol Metab 89:5213-5221

61. Oner J, Oner H, Colakoglu N, Kukner A, Ozan E (2006) The effects of triiodothyronine on rat testis: a morphometric and immunohistochemical study. J Mol Histol 37:9-14

62. Pantos C, Mourouzis I, Saranteas T, Clave G, Ligeret H, NoackFraissignes P, Renard PY, Massonneau M, Perimenis P, Spanou D, Kostopanagiotou G, Cokkinos DV (2009) Thyroid hormone improves postischemic recovery of function while limiting apoptosis: a new therapeutic approach to support hemodynamics in the setting of ischemia-reperfusion? Basic Res Cardiol 104:69-77

63. Pitoia F, Bueno F, Urciuoli C, Abelleira E, Cross G, Tuttle RM (2013) Outcomes of patients with differentiated thyroid cancer risk-stratified according to the American Thyroid Association and Latin American Thyroid Society risk of recurrence classification systems. Thyroid 23: 1401-1407

64. Plow EF, Haas TA, Zhang L, Loftus J, Smith JW (2000) Ligand binding to integrins. J Biol Chem 275:21785-21788

65. Rae MT, Gubbay O, Kostogiannous A, Price D, Critchley HO, Hillier SG (2007) Thyroid hormone signaling in human ovarian surface epithelial cells. J Clin Endocrinol Metab 92:322-327

66. Rusinek D, Szpak-Ulczok S, Jarzab B (2011) Gene expression profile of human thyroid cancer in relation to its mutational status. J Mol Endocrinol 47:R91-R103

67. Sarkozy G, Griesmaier E, He X, Kapelari K, Urbanek M, Simbruner G, Gressens P, Keller M (2007) T3 replacement does not prevent excitotoxic cell death but reduces developmental neuronal apoptosis in newborn mice. Eur J Paediatr Neurol 11:129-135

68. Schmidinger M, Vogl UM, Bojic M, Lamm W, Heinzl H, Haitel A, Clodi M, Kramer G, Zielinski CC (2011) Hypothyroidism in patients with renal cell carcinoma: blessing or curse? Cancer 117:524-544

69. Schmidt JA, Allen NE, Almquist M, Franceschi S, Rinaldi S, Tipper SJ, Tsilidis KK, Weiderpass E, Overvad K, Tjonneland A, BourtronRualt MC, Dossus L, Mesrine S, Kaaks R, Lukanova A, Boeing H, Lagiou P, Trichopoulos D, Tricopoulou A, Palli D, Krogh V, Panico S, Tumino R, Zanetti R, Bueno-de-Misquita HB, Peeters PH, Lund E, Menendez V, Agudo A, Sanchez MJ, Chirlaque MD, Ardanez E, Larranaga N, Hennings J, Sandstrom M, Khaw KT, Wareham N, Romieu I, Gunter MJ, Riboli E, Key TJ, Travis RC (2014) Insulinlike growth factor-1 and risk of differentiated thyroid carcinoma in the European prospective investigation into cancer and nutrition. Cancer Epidemiol Biomarkers Prev 23:976-985

70. Stack BC Jr, Ferris RL, Goldenberg D, Haymart M, Shaha A, Sheth S, Sosa JA, Tufano RP (2012) American Thyroid Association consensus review and statement regarding the anatomy, terminology, and rationale for lateral neck dissection in differentiated thyroid cancer. Thyroid 22:501-508
71. Sterle HA, Valli E, Cayrol MF, Paulazo MA, Martinel Lamas D, Diaz Flaque MC, Klecha AJ, Colombo L, Medina V, Cremaschi GA, Barreiro Arcos ML (2014) Thyroid status modulates T lymphoma growth via cell cycle regulatory proteins and angiogenesis. J Endocrinol 222:243-255, Jun 13. pii: JOE-14-0159 [Epub ahead of print]

72. Sukocheva OA, Carpenter DO (2006) Anti-apoptotic effects of 3, 5, 3'-tri-iodothyronine in mouse hepatocytes. J Endocrinol 191:447458

73. Urken ML, Milas M, Randolph GW, Tufano R, Bergman D, Bernet V, Brett EM, Brierley JD, Cobin R, Doherty G, Klopper J, Lee S, Machac J, Mechanick JI, Orloff LA, Ross D, Smallridge RC, Terris DJ, Clain JB, Tuttle M (2014) Management of recurrent and persistent metastatic lymph nodes in well-differentiated thyroid cancer: a multifactorial decision-making guide for the thyroid cancer care collaborative. Head Neck. doi:10.1002/hed.23615, Jan 17

74. Wang L, Shao YY, Ballock RT (2010) Thyroid hormone-mediated growth and differentiation of growth plate chondrocytes involves IGF-1 modulation of beta-catenin signaling. J Bone Miner Metab 25:1138-1146

75. Wang YY, Jiao B, Guo WG, Che HL, Yu ZB (2010) Excessive thyroxine enhances susceptibility to apoptosis and decreases contractility of cardiomyocytes. Mol Cell Endocrinol 320:67-75

76. Weis SM, Cheresh DA (2011) $\alpha$ v integrins in angiogenesis and cancer. Cold Spring Harb Perspect Med 1(1):a006478

77. Ximenes HM, Lortz S, Jorns A, Lenzen S (2007) Triiodothyronine (T3)-mediated toxicity and induction of apoptosis in insulinproducing INS-1 cells. Life Sci 80:2045-2050

78. Yalcin M, Bharali DJ, Dyskin E, Dier E, Lansing L, Mousa SS, Davis FB, Davis PJ, Mousa SA (2010) Tetraiodothyroacetic acid and tetraiodothyroacetic acid nanoparticle effectively inhibit the growth of human follicular thyroid cell carcinoma. Thyroid 20:281-286

79. Yalcin M, Bharali DJ, Lansing L, Dyskin E, Mousa SS, Hercbergs A, Davis FB, Davis PJ, Mousa SA (2009) Tetraiodothyroacetic acid (tetrac) and tetrac nanoparticles inhibit growth of human renal cell carcinoma xenografts. Anticancer Res 29:3825-3831

80. Yalcin M, Dyskin E, Lansing L, Bharali DJ, Mousa SS, Bridoux A, Hercbergs AH, Lin HY, Davis FB, Glinsky GV, Glinskii A, Ma J, Davis PJ, Mousa SA (2010) Tetraiodothyroacetic acid (tetrac) and nanoparticulate tetrac arrest growth of medullary carcinoma of the thyroid. J Clin Endocrinol Metab 95:1972-1980

81. Yalcin M, Lin HY, Sudha T, Bharali DJ, Meng R, Tang HY, Davis FB, Stain SC, Davis PJ, Mousa SA (2013) Response of human pancreatic cancer cell xenografts to tetraiodothyroacetic acid nanoparticles. Horm Cancer 4:176-185

82. Yeh MW, Rougier JP, Park JW, Duh QY, Wong M, Werb Z, Clark OH (2006) Differentiated thyroid cancer cell invasion is regulated through epidermal growth factor receptor-dependent activation of matrix metalloproteinase (MMP)-1/gelatinase A. Endocrinol Relativ Cancer 13:1173-1183

83. Zhang J, Wang P, Dykstra M, Gelebart P, Williams D, Ingham R, Adewuyi EE, Lai R, McMullen T (2012) Platelet-derived growth factor receptor- $\alpha$ promotes lymphatic metastases in papillary thyroid cancer. J Pathol 228:241-250

84. Zhang L, Cooper-Kuhn CM, Nannmark U, Biomgren K, Kuhn HG (2010) Stimulatory effects of thyroid hormone on brain angiogenesis in vivo and in vitro. J Cereb Blood Flow Metab 30:323-335 